\title{
Role of Plant Growth Regulators on Quality Seed Yield of Bottle Gourd [Lagenaria siceraria (Mol.) Standl.]
}

\author{
Manish Kumar*, Vijay Kumar Singh', Sangeeta Shree', \\ Randhir Kumar ${ }^{1}$ and Arun Kumar ${ }^{2}$ \\ Department of Horticulture (Vegetable and Floriculture), BAC, Bihar Agricultural University, \\ Sabour, Bhagalpur, India-813210 \\ *Corresponding author
}

\section{Keywords}

Plant growth regulators, Stages of spray, Seed and quality, Yield.

\section{Article Info}

Accepted:

18 August 2019 Available Online:

10 September 2019

\section{A B S T R A C T}

An experiment was carried out during summer season, 2018 on "Role of plant growth regulators on quality seed yield of bottle gourd". The experiment was laid out in randomised block design (Factorial) with three levels of NAA (50 ppm, 75 ppm, 100 ppm), $\mathrm{GA}_{3}(50 \mathrm{ppm}, 75 \mathrm{ppm}, 100 \mathrm{ppm})$ and Ethrel (100 ppm, $\left.200 \mathrm{ppm}, 300 \mathrm{ppm}\right)$ and control (P0- distilled water spray) at three stages of spray (S1 - At two true leaf stage, S2 1 st at two true leaf stage and $2^{\text {nd }}$ at four true leaf stage and S3 - 1st at two true leaf stage, $2^{\text {nd }}$ at four true leaf stage and $3^{\text {rd }}$ at flower initiation stage) and replicated thrice. Significantly highest seed yield $(465.22 \mathrm{~kg} / \mathrm{ha})$ was obtained under the foliar application of Ethrel @ 300 ppm sprayed at stage S3 (1st at two true leaf stage, $2^{\text {nd }}$ at four true leaf stage and $3^{\text {rd }}$ at flower initiation stage). Significantly highest number of seeds per fruit (425) was recorded with the $\mathrm{GA}_{3} @ 50 \mathrm{ppm}$ sprayed at stage S3 (1st at two true leaf stage, $2^{\text {nd }}$ at four true leaf stage and $3^{\text {rd }}$ at flower initiation stage) whereas 100 seed weight $(13.48 \mathrm{~g}$ ) was observed in treatment P6S3 (P6- GA 100 ppm and S3-1st at two true leaf stage, $2^{\text {nd }}$ at four true leaf stage and $3^{\text {rd }}$ at flower initiation stage) and found non-significant. The maximum germination per cent $(90.33 \%)$ and seed viability $(95.66 \%)$ were observed when the plant was sprayed with GA3 @ 100 ppm at stage S2 (1st at two true leaf stage and $2^{\text {nd }}$ at four true leaf stage) which was found non-significant. Significantly highest seedling length $(29.33 \mathrm{~cm})$, vigour Index II (53.03), vigour Index I (23.84) and seedling dry weight (0.65 mg)were recorded with application of Ethrel @ 200 ppm applied at stage S2 (1st at two true leaf stage and $2^{\text {nd }}$ at four true leaf stage $)$. Electrical conductivity $(0.54 \mathrm{dS} / \mathrm{cm} / \mathrm{seed})$ was minimum when $\mathrm{GA}_{3} @ 100$ ppm applied at stage S3 (1st at two true leaf stage, $2^{\text {nd }}$ at four true leaf stage and $3^{\text {rd }}$ at flower initiation stage) which was significantly good for the better germination of seed. The maximum net return (Rs 458092) with higher B: C ratio (4.57) was observed with combined effect of Ethrel @ 300 ppm sprayed at stage S3 (1st at two true leaf stage, $2^{\text {nd }}$ at four true leaf stage and $3^{\text {rd }}$ at flower initiation stage). Therefore, it may be concluded that foliar application of Ethrel @ 300 ppm sprayed at three times i.e. at two true leaf stage, four true leaf stage and flower initiation stage was beneficial for higher seed yield and better quality of seed. 


\section{Introduction}

Bottle gourd [Lagenaria siceraria (Mol.) Standl.] is a commonly grown vegetable in India and belongs to family cucurbitaceae. Fruit of bottle gourd shows cooling effect. It shows cardiatonic and diuretic in effect. The pulp is good for decreasing the cough, night blindness, constipation, and act as antidote against certain poisons. It also cure those people who is suffering from biliousness and indigestion. The extract of plant is used as a cathartic and the seeds are used to cure from dropsy. Besides an important vegetable crop, it has also good curative as well as dietary value. The plant growth regulators are well known as a new generation agrochemicals after fertilizers, herbicides and pesticides. $\mathrm{GA}_{3}$, NAA \& Ethrel are important plant growth regulators that may have ability to alter the growth, sex ratios and yield contributing characters of plant (Shantappa et al., 2007).

The discovery of plant growth regulators has been considered as a revolution in the history of agriculture as it has brought amazing vast new possibilities of delicate and wonderful adjustment and development pattern in plants. A growth regulator enables to man to control the plant growth and has become the greater tool in the hands of horticulturist for enhancing yield and better quality of vegetables. Plant growth regulators have immense potential for growth improvement but their application has to be planned sensibly in terms of optimal concentration, stages of application, species specificity and seasons. The use of plant growth regulators at suitable stage play an important role in sex expression and ultimately yield of bottle gourd (Sircar, 1971). In case of cucurbits, the growth regulators are more important due to their outstanding effect on staminate and pistillate flowers ratio, fruit set, fruit drop and ultimately on yield (Bose et al., 1999).
Seed is the basic and cheapest input and forms only a small part of the total cultivation expenses. Yet, without good seed the investment on fertilizers, water, pesticides and other inputs will not pay the required dividends. Hence, good agriculture depends upon good seed and vice-versa. It is economically growing in Ethiopia, Africa and

\section{Materials and Methods}

The present investigation was framed with three levels of NAA (50 ppm, $75 \mathrm{ppm}, 100$ ppm), GA3 (50 ppm, 75 ppm, $100 \mathrm{ppm}$ ) and Ethrel (100 ppm, 200 ppm, 300 ppm) along with control (P0- distilled water spray) and three stages of spray (S1 - At two true leaf stage, $\mathrm{S} 2-1^{\text {st }}$ at two true leaf stage and $2^{\text {nd }}$ at four true leaf stage and S3 $-1^{\text {st }}$ at two true leaf stage, $2^{\text {nd }}$ at four true leaf stage and $3^{\text {rd }}$ at flower initiation stage). The experiment was conducted in RBD (Factorial) with three replications. The spacing of plants were kept $2 \mathrm{~m} \times 1 \mathrm{~m}$. The recommended package and practices were followed for healthy growth and development of the plants. The research work was undertaken at vegetable seed production area under department of Horticulture (Vegetable \& Floriculture), BAU, Sabour, Bhagalpur during summer season, 2018 on variety Narendra Rashmi.

\section{Results and Discussion}

The significant difference were observed for main effect of PGRs and stage of spray as well as their interaction effect on most of the characters studied (Table land 2). The foliar application of $\mathrm{GA}_{3} @ 50$ ppm gave higher number of seeds/fruit (425.00) when spray at stage S3 (2+4 true leaf stage and flower initiation stage) which was statistically similar to $\mathrm{GA}_{3} @ 50$ ppm sprayed at stage S2 $(2+4$ true leaf stage) having 419.00 seeds/fruit and $\mathrm{GA}_{3} @ 100$ ppm sprayed at stage S3 (2+4 true 
leaf stage and flower initiation stage) having 403.00 seeds/fruit and the minimum number of seeds/fruit (232.00) was found under control. The application of PGRs and stage of spray did not touch the level of significance for the test weight of seed. However, application of $\mathrm{GA}_{3} @ 100$ ppm produced the highest 100 seed weight (13.48 g). This might be due to that the plant sprayed with $\mathrm{GA}_{3}$ caused higher vegetative growth, better photosynthesis and greater accumulation of food reserves in seed resulting in higher number of seeds and 100 seed weight. Mehdi et al., (2012) also obtained maximum number of seeds/fruit and 100 seed weight when sprayed with higher concentration of $\mathrm{GA}_{3}$. The minimum test weight $(10.75 \mathrm{~g})$ was observed with application of Ethrel @ 100 ppm at two true leaf stage ( $\mathrm{S} 1$ - two true leaf stage).The interaction effect due to stages of spray and PGRs was found significant on seed yield. The foliar application of Ethrel @ 300 ppm at stage S3 $(2+4$ true leaf stage and flower initiation stage) showed highest seed yield (465.22 kg/ha) followed by application of Ethrel @ 200 ppm at stage S2 (2+4 true leaf stage) i.e. with treatment P9S2 (441.18 kg/ha) and minimum $(299.29 \mathrm{~kg} / \mathrm{ha})$ was found in treatment (P0S1) i.e. when plant sprayed with distilled water at two leaf stage. The highest seed germination (90.33\%), seed viability (95.66 \%)as well as lowest electrical conductivity $(0.54 \mathrm{dS} / \mathrm{cm} / \mathrm{seed})$ were noticed in seed produced from the plant sprayed with $\mathrm{GA}_{3} @ 100$ ppm at stage S3 (2+4 true leaf stage and flower initiation stage).The minimum germination $(79.66 \%)$, seed viability $(85 \%)$ was observed when plant sprayed with distilled water at stage S2 $(2+4$ true leaf stage). This might be due to the better transportation and accumulation of photosynthates to developing fruits resulting in development of filled and bolder seeds. These results are in agreement with the finding of Gedam et al., (1996) and Dostogir et al., (2006) in bitter gourd.

Significantly highest seedling length (29.33), seedling dry weight $(0.65 \mathrm{mg})$, vigour index I (23.85) and vigour index II (53.03) were obtained in seed produced by those plants sprayed with Ethrel @ 200 ppm at stage S2 $(2+4$ true leaf stage) and the minimum seedling length (18.00), seedling dry weight (0.43 mg), vigour index I (14.34) and vigour index II (34.41) were obtained in seed produced by those plants sprayed with distilled water at stage S2 $(2+4$ true leaf stage). This might be due to adequate supply of food reserve to resume embryo growth and synthesis of hydrolytic enzymes which was secreted and act on starchy endosperm in turn affecting physiology of seed germination, establishment of seedlings and ultimately the vigour index. These results were also observed by Hilli et al., (2010) in ridge gourd and Shantappa et al., (2007) in bitter gourd.

It can be concluded that three stages of Ethrel @ 300 ppm at two true leaf stage, four true leaf stage and flower initiation stage was found beneficial for higher seed yield and highest $\mathrm{B}: \mathrm{C}$ ratio.

Whereas maximum germination $\%$, seed viability, and minimum electrical conductivity were recorded with application of $\mathrm{GA}_{3} @ 100$ ppm sprayed at 2 true leaf stage +4 true leaf stage + flower initiation stage. Seedling length and seedling dry weight and seedling vigour index I and II were recorded highest with application of Ethrel @ 200 ppm applied at 2 true leaf stage +4 true leaf stage + flower initiation stage. 
Int.J.Curr.Microbiol.App.Sci (2019) 8(9): 1357-1362

Table.1 Effect of Stages of spray and PGRs on seed quality parameters

\begin{tabular}{|c|c|c|c|c|c|c|c|c|c|c|}
\hline & NS/F & $\begin{array}{l}\text { SY(Kg } \\
\text { /ha) }\end{array}$ & $\begin{array}{l}\text { TW } \\
\text { (g) }\end{array}$ & $\begin{array}{l}\text { GP } \\
(\%)\end{array}$ & $\begin{array}{l}\text { SL } \\
(\mathrm{cm})\end{array}$ & $\begin{array}{l}\text { SD } \\
\text { W } \\
(\mathbf{m g})\end{array}$ & SVI-I & SVI-II & $\begin{array}{l}\mathrm{EC}(\mathrm{dS} / \\
\mathrm{cm} / \\
\text { seed })\end{array}$ & $\begin{array}{l}\text { SV } \\
(\%)\end{array}$ \\
\hline \multicolumn{11}{|l|}{ Stages of spray } \\
\hline S1 & 319.60 & 344.92 & 11.45 & 84.27 & 24.36 & 0.55 & 20.18 & 44.91 & 0.76 & 89.43 \\
\hline S2 & 318.20 & 355.07 & 11.65 & 84.63 & 23.46 & 0.53 & 19.24 & 43.29 & 0.75 & 89.83 \\
\hline S3 & 333.30 & 372.15 & 11.94 & 85.60 & 23.50 & 0.54 & 19.37 & 43.48 & 0.72 & 90.73 \\
\hline Mean & 323.70 & 357.38 & 11.68 & 84.83 & 23.77 & 0.54 & 19.60 & 43.89 & 0.74 & 90.00 \\
\hline $\operatorname{SEm}( \pm)$ & 0.85 & 0.74 & 0.023 & 0.15 & 0.05 & 0.001 & 0.05 & 0.08 & 0.001 & 0.20 \\
\hline $\begin{array}{l}\text { C.D. } \\
(P=0.05)\end{array}$ & 2.41 & 2.11 & 0.065 & NS & 0.13 & 0.003 & 0.15 & 0.24 & 0.004 & NS \\
\hline \multicolumn{11}{|l|}{ PGRs } \\
\hline PO(control) & 247.67 & 301.34 & 11.89 & 80.22 & 20.66 & 0.48 & 17.10 & 38.47 & 0.91 & 85.55 \\
\hline $\begin{array}{l}\text { P1(NAA } 50 \\
\text { ppm) }\end{array}$ & 289.00 & 334.15 & 11.00 & 84.55 & 22.33 & 0.52 & 18.97 & 43.09 & 0.84 & 89.44 \\
\hline $\begin{array}{l}\text { P2(NAA } \\
\text { ppm) }\end{array}$ & 315.67 & 347.09 & 11.15 & 85.55 & 23.66 & 0.54 & 19.14 & 43.36 & 0.81 & 90.11 \\
\hline $\begin{array}{ll}\text { P3(NAA } & 100 \\
\text { ppm) } & \end{array}$ & 299.33 & 347.77 & 11.11 & 85.44 & 25.00 & 0.56 & 20.28 & 45.49 & 0.77 & 90.66 \\
\hline $\begin{array}{l}\text { P4(GA } 3 \text { (G0 } \\
\text { ppm) }\end{array}$ & 407.67 & 313.12 & 11.51 & 86.33 & 23.55 & 0.54 & 20.09 & 44.21 & 0.66 & 91.77 \\
\hline $\begin{array}{l}\text { P5(GA } 3 \\
\text { ppm) }\end{array}$ & 366.00 & 348.31 & 13.13 & 87.44 & 25.44 & 0.57 & 21.11 & 46.22 & 0.64 & 93.55 \\
\hline $\begin{array}{ll}\mathrm{P}_{6}\left(\mathrm{GA}_{3}\right. & 100 \\
\text { ppm) }\end{array}$ & 390.00 & 354.20 & 13.28 & 90.00 & 26.00 & 0.58 & 21.64 & 46.85 & 0.62 & 95.00 \\
\hline $\begin{array}{l}\text { P7(ETHREL } \\
100 \text { ppm) }\end{array}$ & 306.33 & 376.08 & 10.85 & 81.89 & 24.55 & 0.56 & 19.77 & 44.83 & 0.75 & 87.00 \\
\hline $\begin{array}{l}\text { P8(ETHREL } \\
200 \text { ppm) }\end{array}$ & 306.33 & 416.40 & 11.48 & 84.11 & 23.00 & 0.53 & 18.41 & 42.38 & 0.72 & 89.33 \\
\hline $\begin{array}{l}\text { P9(ETHREL } \\
300 \text { ppm) }\end{array}$ & 309.00 & 435.34 & 11.37 & 82.77 & 23.55 & 0.53 & 19.46 & 44.03 & 0.68 & 87.55 \\
\hline Mean & 323.70 & 357.38 & 11.68 & 84.83 & 23.77 & 0.54 & 19.60 & 43.89 & 0.74 & 90.00 \\
\hline $\operatorname{SEm}( \pm)$ & 2.84 & 2.48 & 0.08 & 0.48 & 0.15 & 0.003 & 0.17 & 0.28 & 0.005 & 0.67 \\
\hline C.D. $(P=0.05)$ & 8.04 & 7.02 & 0.22 & 1.37 & 0.43 & 0.010 & 0.49 & 0.79 & 0.014 & 1.90 \\
\hline
\end{tabular}

NS/F- number of seed/fruit, SY(Kg/ha)-Seed yield in Kg/ha, TW- Test weight of 100 seeds (g), GP- Germination $(\%)$, SL-Seedling length $(\mathrm{cm})$, SDW- Seedling dry weight $(\mathrm{mg})$, SVI-I-seedling vigour index I, SVI-II-seedling vigour index II, EC-Electrical Conductivity (dS/cm/seed), SV-Seed viability (\%). 
Table.2 Interaction effect of stages of spray and PGRs on seed quality parameters

\begin{tabular}{|c|c|c|c|c|c|c|c|c|c|c|}
\hline $\begin{array}{l}\text { Treatme } \\
\text { nts }\end{array}$ & $\mathbf{N S} / \mathbf{F}$ & $\begin{array}{l}\text { SY(Kg/ } \\
\text { ha) }\end{array}$ & TW (g) & $\begin{array}{l}\text { GP } \\
(\%)\end{array}$ & $\begin{array}{l}\text { SL } \\
(\mathrm{cm})\end{array}$ & $\begin{array}{l}\text { SDW } \\
(\mathrm{mg})\end{array}$ & SVI-I & $\begin{array}{l}\text { SVI- } \\
\text { II }\end{array}$ & $\begin{array}{l}\mathrm{EC}(\mathrm{ds} \\
/ \mathrm{m})\end{array}$ & SV (\%) \\
\hline P0 x SI & 232 & 299.29 & 11.62 & 80.33 & 21.33 & 0.50 & 19.13 & 40.02 & 0.93 & 85.66 \\
\hline P0 x S2 & 249 & 308.91 & 11.36 & 79.66 & 18 & 0.43 & 14.34 & 34.41 & 0.89 & 86.00 \\
\hline P0 x S3 & 262 & 295.82 & 12.7 & 80.66 & 22.66 & 0.52 & 17.82 & 40.98 & 0.92 & 85.00 \\
\hline P1 x S1 & 276 & 318.47 & 10.85 & 84.66 & 19.66 & 0.49 & 17.58 & 40.42 & 0.85 & 89.33 \\
\hline P1 x S2 & 282 & 334.16 & 11 & 83.66 & 22 & 0.52 & 17.97 & 42.54 & 0.87 & 88.66 \\
\hline P1 x S3 & 309 & 349.82 & 11.16 & 85.33 & 25.33 & 0.55 & 21.36 & 46.30 & 0.81 & 90.33 \\
\hline P2 x S1 & 318 & 329.92 & 10.9 & 84 & 23 & 0.53 & 19.45 & 43.52 & 0.78 & 88.66 \\
\hline P2 x S2 & 270 & 347.68 & 11.2 & 85.66 & 24.66 & 0.55 & 19.32 & 43.08 & 0.84 & 91.00 \\
\hline P2 x S3 & 359 & 363.67 & 11.35 & 87 & 23.33 & 0.54 & 18.66 & 43.47 & 0.80 & 90.67 \\
\hline P3 x S1 & 289 & 337.82 & 11.12 & 85.33 & 27.66 & 0.61 & 21.85 & 48.35 & 0.82 & 90.00 \\
\hline P3 x S2 & 319 & 348.74 & 11.08 & 84.66 & 22.33 & 0.52 & 18.23 & 42.14 & 0.74 & 89.66 \\
\hline P3 x S3 & 290 & 356.76 & 11.14 & 86.33 & 25 & 0.55 & 20.75 & 45.98 & 0.76 & 92.33 \\
\hline P4 x S1 & 379 & 316.58 & 11.36 & 86 & 29 & 0.64 & 23.78 & 52.23 & 0.56 & 91.66 \\
\hline P4 x S2 & 419 & 296.82 & 11.52 & 85.66 & 18.66 & 0.46 & 17.05 & 37.26 & 0.71 & 90.33 \\
\hline P4 x S3 & 425 & 325.95 & 11.65 & 87.33 & 23 & 0.52 & 19.45 & 43.14 & 0.72 & 93.33 \\
\hline P5 x S1 & 391 & 344.72 & 12.78 & 86 & 23.66 & 0.54 & 19.87 & 44.28 & 0.75 & 92.33 \\
\hline P5 x S2 & 346 & 355.46 & 13.24 & 88.33 & 25.66 & 0.58 & 20.87 & 45.85 & 0.56 & 94.66 \\
\hline P5 x S3 & 361 & 344.76 & 13.36 & 88 & 27 & 0.59 & 22.59 & 48.53 & 0.60 & 93.66 \\
\hline P6 x S1 & 393 & 343.81 & 13 & 90 & 25.33 & 0.57 & 20.94 & 47.37 & 0.70 & 95.00 \\
\hline P6 x S2 & 374 & 315.12 & 13.36 & 89.66 & 24.66 & 0.54 & 20.14 & 44.26 & 0.61 & 94.33 \\
\hline P6 x S3 & 403 & 403.68 & 13.48 & 90.33 & 28 & 0.63 & 23.84 & 48.91 & 0.54 & 95.66 \\
\hline P7 x S1 & 319 & 365.79 & 10.75 & 80.33 & 27 & 0.60 & 21.69 & 48.04 & 0.75 & 85.33 \\
\hline P7 x S2 & 291 & 377.46 & 10.88 & 82 & 25 & 0.56 & 20.50 & 46.00 & 0.80 & 86.66 \\
\hline P7 x S3 & 309 & 384.99 & 10.92 & 83.33 & 21.66 & 0.51 & 17.11 & 40.45 & 0.69 & 89.00 \\
\hline P8 x S1 & 273 & 393.24 & 11.14 & 85 & 21 & 0.49 & 16.45 & 38.04 & 0.78 & 90.66 \\
\hline P8 x S2 & 334 & 425.19 & 11.46 & 84.33 & 29.33 & 0.65 & 23.85 & 53.03 & 0.73 & 89.33 \\
\hline P8 x S3 & 312 & 430.78 & 11.85 & 83 & 18.66 & 0.45 & 14.93 & 36.08 & 0.64 & 88.00 \\
\hline P9 x S1 & 326 & 399.61 & 10.95 & 81 & 26 & 0.58 & 21.06 & 46.82 & 0.65 & 85.66 \\
\hline P9 x S2 & 298 & 441.18 & 11.38 & 82.66 & 24.33 & 0.54 & 20.11 & 44.31 & 0.71 & 87.66 \\
\hline P9 x S3 & 303 & 465.22 & 11.78 & 84.66 & 20.33 & 0.48 & 17.21 & 40.98 & 0.68 & 89.33 \\
\hline $\operatorname{SEm}( \pm)$ & 8.52 & 7.44 & 0.23 & 1.45 & 0.45 & 0.011 & 0.51 & 0.83 & 0.015 & 2.02 \\
\hline $\begin{array}{l}\text { C.D } \\
(P=0.05)\end{array}$ & 24.13 & 21.06 & 0.65 & NS & 1.28 & 0.031 & 1.46 & 2.36 & 0.042 & NS \\
\hline
\end{tabular}




\section{Acknowledgement}

Authors acknowledge with thanks to my advisory committee and chairman of Department of Horticulture (Vegetable \& Floriculture), Director Research and Dean, Post Graduate Studies, Bihar Agricultural University, Sabour, Bhagalpur for providing necessary facilities during the course of investigation.

\section{References}

Arvind kumar, PR, Vasudevan, SN, Patil, MG, Rajrajeshwari, and C (2012) Influence of NAA, triacontanol and boron spray on seed yield and quality of bitter gourd (Momordicacharantia) cv. PUSA VISESH. Asian Journal of Horticulture Vol.7 No.1 pp.36-39 ref.7.

Bose, TK, Som, MG, Kabir, J (1999) Flowering, sex mechanism, pollination and fruit set in vegetable crops. Naya Prakash Calcutta, pp.53-54.

Dostogir H, Karim MA, Pramanik MHR, Rehman AAMS (2006) Effect of gibberellic acid (GA3) on flowering and fruit development of bitter gourd (Momordica charantia L.). International
Journal of Botany 2: 329-32.

Gedam VM, Patil RB, Suryawanshi YB, Mate SN (1996) Effect of plant growth regulators and boron on flowering, fruiting and seed yield in bitter gourd. Seed Research. 1998; 26(1): 97-100

Hilli, J S, Vyakarnahal, B S, Biradar, D Pand Ravi H (2010) Effect of growth regulators and stages of spray on growth, fruit set and seed yield of ridgegourd. Karnataka Journal of Agricultural Sciences Vol.23 No.2 pp.239-242 ref.8.

Mehdi M, Ahmed N, Jabeen N, Baseerat Afroza (2012) Effect of ethrel on hybrid seed production of cucumber (CucumissativusL.) under open and protected conditions. The Asian Journal of Horticulture, 2(7): 558-560.

Shantappa Tirakannanavar, Shekhargouda, M, Meharwade, MN and Deshpande, VK (2007) Seed yield and quality as influenced by plant growth regulators and stages of spray in bitter gourd. Seed Research, 35(1) : 11-16.

Sircar, SM (1971) Flowering, parthenocarpy and fruit setting. Plant Hormone Research in India, $1: 11$.

\section{How to cite this article:}

Manish Kumar, Vijay Kumar Singh, Sangeeta Shree, Randhir Kumar and Arun Kumar 2019. Role of Plant Growth Regulators on Quality Seed Yield of Bottle Gourd [Lagenaria siceraria (Mol.) Standl.]. Int.J.Curr.Microbiol.App.Sci. 8(09): 1357-1362.

doi: https://doi.org/10.20546/ijcmas.2019.809.156 